\title{
Literary Correspondence: Letters and emails in Caribbean writing
}

\section{Marta Fernández Campa}

\begin{abstract}
This article explores the role of correspondence (and literary archives in general) in illuminating central aspects of Caribbean literary culture and authors' work, with a consideration of the challenges and the need to preserve email correspondence for archives in the future. This study is part of a larger three-year Leverhulme research project, Caribbean Literary Heritage, now in its initial stage. Led by Professor Alison Donnell (University of East Anglia) with Professor Kei Miller (University of Exeter), with consultancy support from Dr David Sutton (University of Reading), the project focuses on the recovery research of forgotten or less known Caribbean writers and a study of the development of literary archives across generations to explore authors' recordkeeping practices, and the new challenges and possibilities created by born-digital papers.
\end{abstract}

\begin{abstract}
Author
Marta Fernández Campa is a Senior Research Associate at the University of East Anglia. She has previously worked at the University of Reading and the University of Saint Louis, Madrid campus. Her research focuses on literary archives, digital preservation and the role of archival records in writer's creative work. She has published articles in Arc, Anthurium, Caribbean Beat and Small Axe, and has been the recipient of a Fulbright Fellowship and the Center for the Humanities Fellowship at the University of Miami.
\end{abstract}

\section{Introduction}

Caribbean literary archives hold great value for understanding cultural production and literary heritage whilst archival research has been key for the writing (and revision) of histories of Caribbean literature. In the introduction to her special issue of Caribbean Quarterly on Caribbean Literary Archives, Alison Donnell highlights "the significant potential of current research and professional collaborations for enriching, enlarging and democratising the archive". ${ }^{1}$ As Donnell argues, researchers must not avoid confronting the silences and imbalances in the archives. ${ }^{2}$ For example, Evelyn O'Callaghan's Women Writing the West Indies: 1803-1949 (2003), delves into a variety of literary and historical archives to amplify the canon of Caribbean literature and situate the literary production of creole women writers in the nineteenth and early to mid-twentieth century. Similarly, Donnell's critical literary histories, ${ }^{3}$ and recovery research of women writers such as Jamaican Una Marson, have been decisive to revisions of male-centred Caribbean literary history. Donnell's commitment to literary archives and particularly the papers of Una Marson, ${ }^{4}$ who was writing from the 1930s to the 1950s, has resulted in contemporary publications of Marson's selected poems by Peepal Tree Press and two of her plays (London calling and Pocomania) published by Blue

\footnotetext{
${ }^{1}$ DONNELL Alison, 'Introduction' in Special 'Caribbean literary archives' issue of Caribbean Quarterly, 62 (3-4), September-December 2016, p. 307.

2 Ibid.

${ }^{3}$ See DONNELL Alison, Twentieth-century Caribbean literature: critical moments in anglophone literary history, Routledge, London, 2006 and BUCKNOR Michael and DONNELL Alison, eds., The Routledge companion to anglophone Caribbean literature, Routledge, Abingdon, 2011.

${ }^{4}$ The Una Marson Collection is part of the Manuscript and Archive Collection at the National Library of Jamaica. See http://nlj.gov.jm/manuscripts-2/ (accessed 13 May 2018).
} 
Banyan Books ${ }^{5}$ thus enlarging the primary sources readily available to readers. Research in literary archives also informs recent critical work, such as Mervyn Morris' Miss Lou: Louise Bennett and Jamaican culture (2014) ${ }^{6}$ and Glyne Griffith's The BBC and the development of anglophone Caribbean literature, 1943-1958 (2016) ${ }^{7}$. Drawing from this increased engagement with archival research and its potential to challenge and reconfigure the field, this article aims to highlight the important role of literary archival records.

By discussing more traditional correspondence from the 1950s and 1960s, and contemporary uses of the letter and email in the work of Caribbean authors, this article considers the traditional role of correspondence, and also brings attention to the shifting issues affecting access to authors' written interactions in the current moment, and the role of publishing letters and emails today. The establishment of email in the 1990s, the widespread use of computers, and increased work with born digital documents has transformed the look of, and interaction with, authors' papers. Increased digitisation and the future archiving of born digital material is predicted to transform literary archives, as we adapt to necessary practices of digital preservation and heritage. The archiving of born-digital records is currently taking place in large institutions including the British Library, the John Rylands University Library of Manchester (especially their Carcanet Press Archive), and Emory University Library, Atlanta (most notably their Salman Rushdie Collection). I argue that the research and publication of correspondence (letters and emails) can have an influencing impact on current debates of Caribbean literary heritage.

\section{The value and role of correspondence in Caribbean literary culture and history}

The archival collections at The George Padmore Institute (GPI) in North London, which holds the collection of the Caribbean Artists Movement, and other key collections, such as the John La Rose Papers, reflect the crucial contribution that migrant and diasporic communities in Britain have made to the development of Caribbean literary cultures. Trinidadian writer, cultural and political activist, John La Rose founded the Institute in 1991, to ensure the historical record of these contributions in Britain and 11,000 records have been catalogued since. ${ }^{8}$ The creation of the Institute and its archive is linked to the independent publishing house and bookshop New Beacon Books, which La Rose founded in 1966 with his wife Sarah White. Despite their pivotal role in the development of Caribbean literature, New Beacon Books and literary enterprises like the Caribbean Artists Movement (CAM) from the 1960s and 1970s, have received, to date, less critical attention than contributions from other periods such as the BBC radio program Caribbean Voices in the 1940s and 1950s. ${ }^{9}$ However, the CAM archival collection offers a unique insight into the formation of its movement and the influence it has had on Caribbean literature from the 1960s onwards. The correspondence in the collection is particularly revealing of cultural and intellectual networks and the impact of its members' activities and publications.

The materials related to CAM, and now part of the collection, were carefully recorded by its founding members: Jamaican writers Edward Kamau Brathwaite and Andrew Salkey, and Trinidadian author John La Rose. Dr Anne Walmsley, British editor and recipient of the 2018 Bocas Henry Swanzy Award for Distinguished Service to Caribbean Literature,

\footnotetext{
${ }^{5}$ MARSON Una, Selected poems, Peepal Tree, Leeds, 2011; MARSON Una, Pocomania; and, London calling. Blue Moon Publishing, Kingston, 2017.

${ }^{6}$ MORRIS Mervyn, Miss Lou: Louise Bennett and Jamaican culture, Ian Randle, Kingston, 2014.

${ }^{7}$ GRIFFITH Glyne A., The BBC and the development of anglophone Caribbean literature, 1943-1958, Palgrave Macmillan, Cham, 2016.

${ }^{8}$ See GEORGE PADMORE INSTITUTE, Archive Catalogue, https://www.georgepadmoreinstitute.org/archive (accessed 27 April 2018).

${ }^{9}$ See BUSH Ruth, 'New Beacon Books: the pioneering years' in her Beacon of hope. New Beacon Books, London, 2016, pp. 1-48.
} 
participated in some of the meetings and events organised by CAM. In 1992, Walmsley published The Caribbean Artists Movement, 1966-1972: a literary and cultural history, a comprehensive documentary history, which she hoped would "provide information and framework from which others may write the many related studies which CAM stimulates and abundantly deserves." 10 During the 1980s, Walmsley travelled to the Caribbean as she carried out research for her book, and had access to CAM's records, which were in private hands. Original records, as well as copies, transcripts and some new records resulting from her own research and interviews during that time, are now part of the Caribbean Artists Movement collection at the George Padmore Institute. When the collection was deposited at the Institute, most of the material had already been organised chronologically by Walmsley, and archivist Sarah Garrod decided to preserve this order when cataloguing the collection, partly in order to offer a narrative of the development of CAM over time.

Despite the short lifetime of the Caribbean Artists Movement (1966-1972), its activity and organisational work were intense and, for the most part, carefully documented. In fact, from its beginnings, the movement was characterised by an archival preoccupation and an acute awareness that materials related to the movement were important evidence to preserve. Walmsey notes how CAM's founder-members recorded all written and audio documents from the start (such as correspondence, conference programs and tapes of conference sessions and other events) with an awareness of their future archival value, as they "always envisaged that its history would, in time, be fully documented and made public." 11 Conference papers and related writing appeared in Savacou: a journal of the Caribbean Artists Movement, which ran from 1970 until 1980 producing fifteen issues, and which remains a central reference of Caribbean artistic expression today.

The archival drive, clearly influenced by Kamau Brathwaite's work as historian, formed part of the movement's self-reflective nature. Brathwaite's unremitting efforts to invigorate engagement in the development of the movement (also as secretary of CAM) is evident in his letters. These demonstrate how key communication and outreach was to grow and gain support. However, Walmsey rightly warns of the limitations of only acknowledging the palpable written archival materials without consideration of what remains outside the boundaries of the archive. She explains how "letters record how things were done, by whom, how people and events were regarded; but telephone calls and face-to-face conversations have left nothing behind." 12 It is known, for example, that Andrew Salkey and John La Rose (as well as Donald Hinds and James Berry) communicated mostly through telephone conversations, and a lot of important discussions and networking took place after formal events, in people's homes. ${ }^{13}$

Most letters in the archive mark exchanges between Brathwaite and British and Caribbean writers, academics, journalists and editors. The first letter in the collection, from 30 November 1966, is addressed to Bryan King, a Kittian university lecturer in jurisprudence at Cambridge University, where Brathwaite completed his BA in History in 1953, followed by a doctorate at the University of Sussex in 1968 on The development of Creole society in Jamaica. Brathwaite regrets the lack of encounters among West Indian writers and artists, as well as with those from Britain and the Commonwealth. He writes on the importance for these groups to know more about West Indian literature, and for West Indian writers to

${ }^{10}$ WALMSEY, Anne, 'Preface' in The Caribbean Artists Movement, 1966-1972: a literary and cultural history, New Beacon Books, London and Port of Spain, 1992, xix.

11 Ibid.

12 Ibid.

${ }^{13}$ Ibid. 
discuss the work of British and Commonwealth authors. ${ }^{14}$ Brathwaite manifests the wish to create a space to enable that very crucible of conversation, asking King for feedback on setting up the space. In his letter, the vision for the movement is wide, both interdisciplinary and comparative as he mentions they would "attempt to discuss the work of French and Spanish-Speaking West Indians", ${ }^{15}$ an element that foregrounds critical efforts at connecting Caribbean literature and art across linguistic groups and geographies that continues today. King's prompt reply is enthusiastic and encouraging; he offers advice on logistical and organisational elements suggesting the West Indian Students Centre as a meeting venue and some people who might be interested. Edward Lucie-Smith, a British literary and art critic, and one of the names King suggests Brathwaite contact, was the recipient of the next letter. ${ }^{16}$ To Brathwaite's introduction of the CAM and an invitation to a group meeting, Lucie-Smith replies encouragingly five days later, and suggests applying "to the Arts Council Literature Panel for a grant. Do it this way round - don't apply for a grant in order to set up a group: they won't wear it." 17

In December 1966, Brathwaite also wrote to Trinidadian Professor Emeritus and literary critic Kenneth Ramchand, then a doctoral student in Caribbean literature at Edinburgh University, and soon afterwards the author of the seminal book of criticism The West Indian novel and its background (1970), a foundational publication of Caribbean literary studies. In their exchange, they discussed the scope and vision for the movement. Brathwaite requests support and seeks input from Ramchand on future events in his first letter. ${ }^{18}$ Ramchand's handwritten response to Brathwaite is a fitting example of the ways in which letters can manage to capture the enthusiasm and engagement of new intellectual projects. Among other things, Ramchand expresses his firm belief that an approach to the issue of the 'West Indian aesthetic' "should involve function and interdisciplinary approaches." ${ }^{\prime 19}$ Interdisciplinary practice and an ongoing debate on interdisciplinarity were characteristic of the movement, and some of the key elements that would foreground future directions in Caribbean studies, still resonant today. ${ }^{20}$

Ramchand's work has been key to the development of literary archives in the Caribbean region, and upon returning to the Caribbean in the late 1960s as a lecturer of literature at the University of the West Indies, in Jamaica, he continued to be involved in archival acquisitions. ${ }^{21}$ Thanks to his work as a critic but also to his relationship with authors, Ramchand facilitated the acquisition of manuscripts and papers by authors such as Wilson Harris, Roger Mais, Michael Anthony (all at the University of the West Indies at Mona), and Eric Roach, Derek Walcott, Samuel Selvon, Earl Lovelace, Michael Anthony and Dennis Mahabir (all at the University of the West Indies at St Augustine). Discussing the role of "manuscripts, letters and other documents" by Caribbean writers working in the period 1950-

\footnotetext{
${ }^{14}$ Edward Brathwaite to Bryan King (30 November 1966): GB 2904 CAM/3/1. The CAM Collection is held at the George Padmore Institute.

${ }^{15}$ Ibid.

${ }^{16}$ Bryan King to Kamau Brathwaite (3 December 1966): GB 2904 CAM/3/2.

${ }^{17}$ Edward Brathwaite to Edward Lucie-Smith (12 December 1966): GB 2904 CAM/3/4.

${ }^{18}$ Edward Brathwaite to Kenneth Ramchand (28 December 1966): GB 2904 CAM/3/6.

${ }^{19}$ Emphasis in the original text, Kenneth Ramchand to Edward Brathwaite (4 January 1967): GB 2904 $\mathrm{CAM} / 3 / 7$.

${ }^{20}$ As a movement, CAM was pioneering in bringing together Caribbean writers including C. L. R. James, Wilson Harris, Michael Anthony, Brathwaite and Salkey, among others, as well as visual artists such as Audrey Williams, Clifton Campbell and Ronald Moody.

${ }^{21}$ RAMCHAND. Kenneth, 'The lost and alienated manuscripts of West Indian writers', Caribbean Quarterly, 62 (3-4), September-December 2016, p. 322.
} 
1970, Ramchand stresses the value of the sometimes-prolific correspondence among writers and the need to collect and preserve those letters. ${ }^{22}$

The correspondence in the collection offers invaluable insight into the organisational aspects and the challenges in setting up a project as ambitious and large in its reach as CAM. Among other aspects, it reflects the vision and determination of its members alongside the role of dialogue, including disagreement, in shaping the development of the movement. Numerous letters exchanged weekly and sometimes daily, manifest Brathwaite's active efforts to kick-start and ensure CAM's success; the correspondence documents, and is proof of, the achievements resulting from ongoing dialogue. Additionally, letters in this collection tell important stories around interactions between authors and editors, for example, as is the case of an exchange between Brathwaite and British editor Diana Athill. ${ }^{23}$

Other collections of letters in literary archives, such as the Henry Swanzy Papers, equally offer valuable insights into the influencing role of editors and publishers. ${ }^{24}$ Swanzy, producer of the BBC radio program Caribbean Voices (1946-1954) - first conceived by Una Marson-, is credited for having played a central role in the promotion and publishing of Caribbean writers. His exchange of correspondence with Gladys Lindo, editor of the program in Jamaica, tells a story of how their collaboration shaped the reviewing and selecting for broadcast from the unpublished work of many authors, largely men but also women. Further, this collection includes a revelatory exchange between Swanzy and Derek Walcott, which leaves record, and offers a sense, of Walcott's unpublished novel A Passage to Paradise (which appears lost today).

As the examples above show, the correspondence of writers embedded in Caribbean literary archives, have the potential to deepen our knowledge and sense of the making of literary culture and history. They offer previously hidden insights into an array of networks, relationships, knowledge and skills that contemporary researchers can draw on in their detailed engagements with the region's literary past.

\section{Letters/emails in the work of Caribbean authors today: Kei Miller's 'Cold onion chronicles'}

Technological developments have, of course, drastically altered our means of communication. The advent of email in the late nineties and its prevalence since the millennium has largely taken over traditional correspondence of postal letters. This presents a pressing issue that bears new challenges and implications for literary archives today; technically, legally and ethically.

The technical complexities of archiving born-digital records, as opposed to traditional paper-based records like letters, brings into focus the complications of archiving emails, particularly as the protocols and procedures of born-digital archives continue to develop. In her article 'Emails to an editor', Fran Baker details the intricate process of archiving the combined email correspondence of Michael Schmidt as poet, editor, friend to many other writers, and Managing Editor of the Carcanet Press. ${ }^{25}$ Another consideration that increases in complexity with email collections is access. Literary scholar Lise Jaillant notes: "For a researcher, getting access to emails is much more complicated than getting access to

\footnotetext{
22 Ibid.

${ }^{23}$ Edward Brathwaite to Diana Athill (2 October 1097): GB 2904 CAM/3/222; Diana Athill to Edward Brathwaite (3 October 1967): GB2904 CAM/3/224.

24 The papers of Henry Valentine L. Swanzy are deposited in the Cadbury Research Library, University of Birmingham (MS42).

${ }^{25}$ BAKER, Fran, 'E-mails to an editor: safeguarding the literary correspondence of the twenty-first century at the University of Manchester Library' in New Review of Academic Librarianship, 21, 2015, pp. 216-224.
} 
letters." ${ }^{26}$ In an article published in the Times Literary Supplement, Jaillant mentions the Carcanet Press archive as an example of an archive closed to researchers (at the time of the article's publication in November 2017), and suggests that the main reasons which delay access to literary archives are "privacy concerns, copyright and technical issues." Yet, interestingly, despite all these complications, email has attracted significant critical attention and has become one of the safest born-digital records to preserve. As Sutton points out "emails are much safer to collect" than other digital collections and "are often more revealing than collections of letters" due to the more casual nature of emails and how they reflect a greater "lack of restraint" in contrast to letters ${ }^{27}$; a point also raised by Jaillant in "Reading Ian McEwan's correspondence". If preservation is easier but access and research is still often complicated, it becomes important to question the disconnection between the two, especially as Jaillant argues "Literary correspondence today is largely born-digital, and the preservation, access and use of these born-digital records is central to our heritage." 28 This issue was raised during presentations and conversations at the second editions of the Digital Preservation Coalition Workshop 'Email preservation: how hard can it be? 2', ${ }^{29}$ and the 'After the Digital Revolution' workshop ${ }^{30}$ (organised by Lise Jaillant), both of which took place in London on January 2018.

Writers' correspondence today is mostly taking place via email; it becomes necessary to assess its role for Caribbean authors. So far, most researchers' access to writers' emails is through their gradual inclusion in non-fiction writing. Before comprehensive future studies of Caribbean born-digital collections can take place one day, it becomes important to create a dialogue about the value of correspondence both in authors' personal papers and in publications. This second section of the article, examines the role that correspondence (emails and letters) can have for contemporary Caribbean literary culture. Email correspondence offers a unique perspective into writers' creative processes, narrative style, and the formation of a writer's identity. 'The cold onion chronicles', a series of emails by Jamaican writer Kei Miller, published in his doctoral thesis, are a good example of records that offer a rare insight into the intersection of an author's personal, creative and political voice. 'The cold onion chronicles' offer privileged access to an authors' email records, which are rarely published due to copyright and/or legal clearance, and therefore remain overwhelmingly private, in strict contrast to other, more visible, writing activity and digital 'archives' such as social media or blogs.

Miller's emails also give a sense of different stages of his early literary career as an emerging writer, a few years before he became an internationally renowned and awardwinning author, recipient of the Forward prize in 2014, and an active poet, novelist and essayist as well as a professor of literature and creative writing at the University of Exeter. Miller's doctoral thesis (published in 2012 at the University of Glasgow), situates the role of epistolary writing in Caribbean literature and culture. Through the discussion and analysis of a wide range of epistolary examples (from the letters of Alexander Bustamante and V.S. Naipaul, to the Jamaican popular advice column 'Dear Pastor', as well as the use of the

\footnotetext{
${ }^{26}$ JAILLANT Lise, 'Reading Ian McEwan's correspondence' in The Times Literary Supplement, 21 November 2017, https://www.the-tls.co.uk/articles/public/ian-mcewans-emails-letters/ (accessed 14 May 2018).

${ }^{27}$ SUTTON David C., 'The destinies of literary manuscripts, past present and future', in Archives and Manuscripts, 42 (3), 2014, p. 299 (pp.295-300).

${ }^{28}$ JAILLANT Lise, 'Reading Ian McEwan's correspondence' op. cit.

${ }^{29}$ DIGIT AL PRESERVATION COALITION, 'Email preservation: how hard can it be? 2', London, Woburn House, 14 January 2018, https://www.dpconline.org/events/past-events/email-2018 (accessed 14 May 2018). The website includes summaries and documents from the presentations.

30 'After the digital revolution', workshop \# 2, London Campus, Loughborough University, 25-26 January 2018, http://www.afterthedigitalrevolution.com/2018/01/slides-workshop-2-after-digital.html (accessed 14 May 2018). This link provides slides from some of the presentations.
} 
epistolary form in literature of the anglophone Caribbean), Miller frames the historical role and cultural significance of letter writing in the Caribbean. Making a compelling case for the ways in which physical letters, email and social media can create diasporic connections and, at times, also signal disconnection, Miller invests the letter with a new relevance for literary studies.

The very composition of Miller's thesis, Jamaica to the world: a study of Jamaican (and West Indian) epistolary practices, itself begins with an epistolary gesture. At the end of the Introduction, Miller consciously disrupts the conventions of academic writing with a particular objective in mind:

In closing, though I realize it may not be the convention of academic prose to express the wish that its readers enjoy the journey of its arguments or 'di course of its discourse', I express that wish right now.

$$
\begin{aligned}
& \text { Sincerely Yours, } \\
& \text { Kei Miller } \\
& \text { University of Glasgow }{ }^{31}
\end{aligned}
$$

This disruption gestures to an understanding of academic writing as a form that can also be subject to revision and productive of cross-discursive, multi-genre and interdisciplinary registers. This discursive hybridity is itself exemplified in Miller's own thesis, as he engages in literary and cultural criticism, analysis of popular culture and history, literary history and a reflective use of correspondence, which arguably blurs the boundaries of the non-fiction genre.

The letters that Miller discusses in Jamaica to the World, as well as his own emails, reveal the impact of the separation inevitably caused by migration, warning readers against an edulcorated portrayal of that experience, and against romanticising transnationalism. Miller quotes Bauer here to support his claim: "Elaine Bauer notes in her own studies of transnational Caribbean families that 'for [those] whom we interviewed, transnationalism is not a figment of the researcher's imagination but a reality both in the mind and in practice.' (Bauer 2006: 2)"32. In this vein, Miller seems to be implicitly commenting on a tendency in postcolonial studies, that celebrates transnationalism through a rhetoric of fluid movement and cultural exchange that, at times, overlooks, and thus occludes, the restrictions imposed on migrant communities, their lived experience and the consequences this brings.

In the final chapter, Miller's inclusion of a sequence of emails initiated upon arriving in England in 2004, reveals his own awareness of, and inscription into, the Caribbean epistolary tradition he is himself also addressing critically. It also signals email and social media as necessary new sites of literary value as they become spaces where writers, universities, cultural groups and others, are documenting contemporary literary history and culture. Miller points out: "[e]mail technology as well as other social media platforms such as Facebook, the blogosphere and Twitter, ought to be considered as the new places in which West Indian epistolography lives and is practiced." ${ }^{33} \mathrm{He}$ explains that he chose the name "The Cold onion chronicles' for these series of emails in response to those sent by his friends Nadia Ellis and Stephen Russell whilst they were Rhodes scholars in Oxford years previously. Ellis and Russell, both professors of Caribbean literature and religion today,

\footnotetext{
${ }^{31}$ MILLER, Andrew Kei, Jamaica to the world: a study of Jamaican (and West Indian) epistolary practices. $\mathrm{PhD}$ thesis, University of Glasgow, p. 26, http://theses.gla.ac.uk/3597 (accessed 14 May 2018).

32 BAUER, Elaine quoted in MILLER, Andrew Kei, Jamaica to the world, op. cit., p. 64.

${ }^{33}$ MILLER, Andrew Kei, Jamaica to the world, op. cit., p. 148.
} 
humorously named them The Colonial Chronicles, and Miller re-fashioned his own in what he describes as a "spoof" of the original series. ${ }^{34}$

The emails range from September 2004 to November 2007, and appear in chronological order. To a great extent, they reflect another important 'journey', as Miller documents his own experience of migration, arriving in London as a Jamaican writer and moving to Manchester to complete an MA in creative writing. This period marks various moments along the process of his then emerging literary career and life in Britain. Similarly, and as the author points out, the emails mark the final destination of his thesis as "the exciting and burgeoning field of the digital humanities", after critical transitions from literary to cultural studies. 'The Cold onion chronicles' is itself — as a series of emails - at the crossroads of these fields of literary, cultural studies, and digital humanities, both in terms of how they are annotated by Miller, and in the research opportunities they present.

In this document, Miller reflects on the risks that affect email correspondence and the process of digital recovery: "I present a set of letters which also could have been lost, but were more easily lassoed. They have been recovered from outboxes on Gmail, or as emails sent back to me on request - my own letters readdressed to their original dispatcher, and now readdressed to you." 35 We also learn that the emails have been edited slightly with some sections not included, in what Miller terms a shortened version of the chronicles. They also contain footnotes to provide further context whether through translating Jamaican patwa (or patois), self-reflectively commenting, or bringing attention to the literary or cultural elements in the emails themselves. For example, there are several intertextual references to Samuel Selvon's The lonely Londoners (1956). The first is in the title of part one of chronicle \#1 from September 2004, which refashions a line from Daisy, a young British white woman in Selvon's novel as she replies to Gallahad, a Caribbean migrant: "I can't take the way you West Indians speak". In Miller's email this is followed by; "said the West Indian woman", to allude to an experience of prejudice as he arrives in London, from relatives who are West Indian migrants themselves. Further, the first line in the email: "Dear friends, I arrived in London, and it was a cold day as if there is no other way to arrive in this city; [...]" 36 both describes the scene and becomes reminiscent, especially after the contextual note, of the arrival scene in The lonely Londoners that describes "one grim winter evening". ${ }^{37}$ Later, the first part of Chronicle \#8, sent on 26 January 2005, refers to Selvon's novel both in its title: "What an awful time is winter (with apologies to Selvon)", and the narrative style. The title is alluding to the unpunctuated section in the middle of The lonely Londoners. Like Selvon's, this part of Miller's email is a flowing stream of text, offering a humorous "reverse" to Selvon's ode to the streets of London "to celebrate what a time it is when summer come to the city". 38 These playful and comic undertones are characteristic of Miller's incisive humour, which has a particular force in his work, and is present in the chronicles. It often starts in the titles, which themselves anticipate the content and focus of sections in the messages: "Did you know that if temperature is increased gradually a human can boil to death without realizing it" (p. 158); "In the land of glitter, lime light and rejections" (p. 171) or "Cold onion chronicles \# (who knows by now?)".

The emails' literary exploration of narrative form is reminiscent of Miller's concern with narrativity in his own writing. This concern is present in the metanarrative elements in The Warner woman (2010); the use of interspersed narratives and epistolary chapter in The same earth (2008), or the questioning of the mapping of "othered" landscapes and

\footnotetext{
${ }^{34}$ Ibid., p. 156.

${ }^{35}$ Ibid., p. 155.

${ }^{36}$ Ibid., p. 156.

${ }^{37}$ SELVON Samuel. The lonely Londoners. Longman, London, 1979. p. 23.

${ }^{38}$ Ibid., p. 101.
} 
philosophies in The cartographer tries to map a way to Zion (2014). Further, Jamaica to the world reflects on the personal, political and cultural value of correspondence, particularly in the Caribbean (both locally and transnationally), a concern that extends to other works. For example, the essay "A Smaller Song” in Writing down the vision (2013) is dedicated and addressed to Jamaican writer and LGBT+ activist Thomas Glave, showing the influence of the letter as a form of political address. Short stories such as "Walking on the Tiger Road" and "Government cows" in Fear of stones and other stories (2006), include sections of letters ("Government cows" being a letter) that poignantly expose the experience of loneliness in migration, the social isolation and violence in multiple acts of homophobia, and the erasure of rural and working class experience, respectively.

The 'Cold onion chronicles' also reveal Miller's own experience of, and political commentary on, anti-black racism in the UK. In one of the last chronicles' sections "Part 3: Dark days for dark men" sent on 9 August 2005, Miller addresses the 2005 London terrorist attacks and its aftermath with the police killing of Brazilian student Jean Charles de Menezes, and an increase in attacks and killings of blacks and Asians, following the attack. Miller explains how, in the media, the anti-immigrant xenophobia and anti-black racism that emerged after the attacks is discursively presented as "[j] ust a slight misunderstanding", and adds, "I think it all might really be my cue to leave. Go back home. Etc."39

The political aspect of Miller's writing extends to all genres, but in his emails, published essays and blog posts, it appears in more detail and in specific reference to issues on literature, gender, race, class (and their intersection). Miller writes regularly in his blog Under the Saltire flag ${ }^{40}$, where he has a high level of response and engagement from wide audiences, mostly from Jamaica, weighing in on the topics. In the blog itself, he explains how that is the platform where he tests out ideas for future essays (some of which have been included in the collection Writing down the vision (2013). In an epistolary type of address resembling that of his thesis, he introduces the line for his blog and, again, places emphasis on his hope that readers may enjoy them:

They are often polemic - and often angry about social injustice, especially those surrounding issues of race and gender - I'm sorry about that. But I hope they're always honest, and even in this draft-stage, that these are things you might enjoy reading. ${ }^{41}$

The "draft stage" of the blog often works in combination with some Miller's interaction with Facebook, as a place where he also comments and shares news about blog posts and other issues. Rebecca Romdhani considers Miller's blog posts and Facebook posts as genres of significance in his writing, and argues that "his online work shares traits not only of the essay, but also creative non-fiction." ${ }^{2}$ Miller's online 'archive' can also be read in conversation with his engagement with Caribbean epistolary forms in Jamaica to the world. Miller's 'The Cold onion chronicles' offer an insight into a wide range of life experiences as a Jamaican writer, student and emerging author in England and also how these may shape and fuel Miller's own creative and artistic voice, particularly in his voice as an essayist, with a great following and engagement in his blog. Additionally, his emails also embody a record where Miller identifies first referencing to his new professional name as an author using his middle name in 'Kei Miller', instead of 'Andrew Miller' which was already in use.

\footnotetext{
${ }^{39}$ MILLER Andrew Kei, Jamaica to the world, op. cit., p. 190..

${ }^{40}$ See Under the Saltire Flag, https://underthesaltireflag.com (accessed 10 March 2018).

${ }^{41} \mathrm{https}$ ://underthesaltireflag.com/about (accessed 20 March 2018).

42 Romdhani, Rebecca, 'Minor genres and marginal realities: Kei Miller's blog posts and Facebook notes', Journal of Postcolonial Writing, 54 (1), 2018, p.100.
} 
As with the letters in the CAM collection and the Henry Swanzy Papers, Miller's emails document the drive shaping literary projects, creative processes and careers. The last of Miller's emails, included in his thesis, 'We stay on the lava ground', concludes the series with a determination to embrace unapologetically his own success, in an honest account where he reflects on other writers' jealousies, and quotes Jamaican reggae artist I - Wayne's song "Lava ground" to assert his position:

We deya pon de lava ground

And nuff a dem a look fi see I mawga down....

But tell dem seh de warriors naah guh run!

We naah guh run!

We deya pon de lava ground.

In a footnote, Miller writes: "A song of resilience, the lyrics would translate to: We stand up on the lava ground/Lots of them would love to see we starve/ But tell them, as a warrior, I will not run/ I will not run!/We stand up on the lava ground."

Emails are included in other recent Caribbean non-fiction collections, and are increasingly gaining force as medium to channel and address social and political commentary. In Blank, a collection of out of print and new essays and interviews, Tobagonian writer M. NourbeSe Philip, includes a selection of letters and emails. In the email "The morning after" an email to an American friend, also based in Canada, Philip writing "in the still-dark, early-morning hours" (p. 325), reacts to the Republican victory and captures some of the campaign's rhetoric whilst referencing US popular talk shows such as SNL, The Daily Show, and Democracy Now!. The email opens with an encoded expletive: “**\&!\#\&\%\#\#!!!<<!!@\#\#!! I should use emoticons if I could, but I think you get the drift."43 In an email published in Carolina De Robertis Radical Love, Dominican-American writer Junot Díaz writes to his sister in the wake of Trump's victory. She appears anonymised as 'Q': "what now? you asked. And that was my students' question, too. What now? I answered them as poorly as I answered you [...]"44 Zadie Smith, British writer of Jamaican heritage, also includes an excerpt from an email to a friend in her essay "Fences: a Brexit Diary"45 which interconnects the results of the European Referendum in Britain with various layers of domestic inequalities across race and class. Correspondence as modelling and informing socio-political writing has become popular in the current moment, particularly as a result of a revival of James Baldwin's epistolary essay 'My dungeon shook: letter to my nephew' (1963) where he tackles the effects of institutionalised anti-black racism. Baldwin's essay has influenced recent US non-fiction such as Ta-Nehisi Coates' Between the world and me (2015), Radical hope: letters of love and dissent in dangerous times (2017), edited by Carolina De Robertis and The fire this time: a new generation speaks about race (2017), edited by Jesmyn Ward. The latter includes essays (some of which are epistolary) by Caribbean writers such as Claudia Rankine, Edwidge Danticat and Daniel José Older.

\section{Conclusion}

The influence of digital technology from the 1990s onwards has had major effects in shaping present and future literary archives, as well as literary works; this is particularly evident in the case of correspondence. Lisa Stead identifies an archival turn in the study of literary archives "where issues of the digital make more insistent claims on preservation and the ways in

\footnotetext{
${ }^{43}$ PHILIP M. NourbeSe, 'The aftermath', in Blank: essays and interviews, Book Thug, Toronto, 2017, p.329.

${ }^{44}$ DÍAZ Junot, 'Radical hope' in DE ROBERTIS Carolina, ed., Radical hope: letters of love and dissent in dangerous times. Vintage Books, New York, 2017, p. 12.

${ }^{45}$ SMITH, Zadie, 'Fences: a Brexit diary' in Feel free: essays, Hamish Hamilton, London, 2018.
} 
which we make use of its materials". ${ }^{46}$ The issues of access and value are central and often intertwined. Stead terms the "archival boundaries" as concerning "the processes by which this material is archived and the barriers, both crossable and uncrossable, that these processes create for both the researcher and the archivist in terms of access, selection, weeding, sealing and digitizing" 47 which in the case of born-digital material becomes even more pressing. In his comprehensive analysis of the future of literary archives, David Sutton points out how "so far, this is happening rather less than would have been predicted 10 years ago." 48

The examples from Caribbean archival records, literary texts and criticism discussed here do cross and trespass the boundaries of the archive. The ways in which emails, letters and journal entries figure in the creative work and publications of writers from the Caribbean signal opportunities to bring archival records closer to readers and also contextualise their role in the intellectual and writing process, blurring the boundaries between source, creative process and critical commentary. They also highlight the inequities and power structures embedded in a variety of 'archives' from the colonial archive to the media, where black subjects are both inscribed and erased through racist narratives. The body of work of M. NourbeSe Philip reflects (upon) such critical engagement. For instance, some of the essays in Blank (both old and new), follow the epistolary tradition that Miller describes in his doctoral thesis, and situate the letter as a political document. The first letters included in Blank, were originally published in Philip's 1992 essay collection Frontiers. The first one is a letter that Philip sent to Canada's newspapers Globe and Mail (1990) as critique, and in response, to experiences of misrepresentation and racism she has experienced in Canadian media outlets from the late 1980s. She has also included other records and journal entries in her poetry book She Tries Her Song, Her Silence Softly Breaks (1989), and essay collections such as A Genealogy of Resistance (1997), (among others) which function as paratext that explore the role of language and discourse in perpetuating oppression. Most recently, Philip has included journal entries and colonial records such as the insurance dispute claim Gregson v. Gilbert (1783), regarding the case of the Zong massacre, in her long poem Zong! (2008). It seems relevant to ask whether these modes of inclusion of archival documents in literary texts, could one day extend to the publication of emails by Caribbean authors? Could the publication of Caribbean literary letters, such as V.S. Naipaul's Letters Between a Father and Son $(1999)^{49}$, one day find a corresponding example in email writing? What would this shift reveal and what window would it open into the literary culture of the late twentieth and twenty-first century?

This paper has discussed the prolific body of correspondence in a selection of Caribbean literary archives. Collections such as the Caribbean Artists Movement were configured with an acute sense of their present and future value for Caribbean literary heritage. This is evident in the varied types of letters: sometimes carbon copies, other times typed transcripts prepared by Anne Walmsey, or, as is the case of Ramchand's handwritten letters, handed to the archive with an understanding of their documentary significance. Correspondence, from C. L. R. James and the Derek Walcott Papers at the Alma Jordan Library in Trinidad, to CAM's archive at the George Padmore Institute or Swanzy's papers at the Cadbury Research Library in the UK, offers invaluable insight into literary cultures in,

\footnotetext{
${ }^{46}$ STEAD Lisa, 'Introduction' in SMITH Carrie and STEAD Lisa, eds., The boundaries of the literary archive: reclamation and representation, Routledge, London, 2016. p. 1.

47 Ibid., p.3.

${ }^{48}$ SUTTON David C., 'The destinies of literary manuscripts, past present and future', in Archives and Manuscripts, 42 (3), 2014, p. 299 (pp.295-300).

${ }^{49}$ For a fascinating discussion of the collection of letters and controversy surrounding Naipaul's objection to the publication of a second edition in 2009, see LAUGHLIN Nicholas 'Naipaul's letters between a father and son (and mother and sister)', Caribbean Quarterly, 62 (3-4), September-December 2016, pp. 406-421.
} 
and across, locations. The question remains, what will the future of Caribbean correspondence look like? The websites of literary festivals such as NGC Bocas Lit Fest in Trinidad, Bim Lit fest in Barbados or Calabash literary festival in Jamaica are further documenting literary history, together with platforms from social media to university and community projects. However, the extent of what its being captured is limited and the preservation of the digital cannot be taken for granted nor guaranteed, and this applies to the digital content in author's papers. The increasing interest in publishing emails as a means to add to, respond, and contextualise the non-fiction work of Caribbean writers, is a helpful and necessary step to engaging and claiming their value, and also redefines what is considered as archive and its boundaries. 